\title{
THE TRUE PRIVATE COST OF A "FREE" UNIVERSITY EDUCATION: A COMPARATIVE STUDY
}

\author{
Marilou Ioakimidis \\ University of Peloponnese, Greece \\ National and Kapodistrian University of Athens, Greece \\ E-mail: marilou@uop.gr \\ George Papakonstantinou \\ National and Kapodistrian University of Athens, Greece \\ E-mail: gpapako@ppp.uoa.gr
}

\begin{abstract}
The ostensibly free university education in Greece actually has several private costs. A comparative research design was used to compare Greek families' private expenditures for university education in 2014-2015 to families' costs for the same education in the year 2000 to determine whether there have been any changes during ensuring years. Data were gathered from a 2014-2015 survey of a random sample of over 2.300 Greek first-year university students and compared to results from a similar survey of over 3.000 first-year university students conducted in the year 2000. Income elasticity of demand was the theoretical framework used to examine and compare results. As with the older survey data, it is shown that despite the "free education" supposedly available in Greece, families actually still spend more than the state in preparing students for and supporting them at a university. It is also demonstrated that lower-income families spend a higher share of income on a university education for their children, a discrepancy that has grown over the past 13 years. Finally, it is shown that private expenditures for a university education appear to remain a necessity in Greece, with income elasticity calculated at between 0.2 and 0.3. Results suggest the need to reallocate the Greek university budget to help relieve the financial burden on families of lower-income students. Results also suggest the importance of reducing the Greek emphasis on expensive preparation of secondary students for national university entrance examinations. Keywords: Greece, higher education, private tutoring, university finance.
\end{abstract}

\section{Introduction}

The constitutional mandate of free higher education in Greece, aligned with the widespread view that the key to a better-paying job in Greece is higher education, has helped create an excessive demand among Greek citizens for a university education. This excess of demand over supply has resulted in a rationing of student access to higher education and an ultra-competitive atmosphere in which scoring well on the Greek national examination that is the gateway to university entrance is seen as imperative among Greek students and their families. This competition has resulted in the proliferation of private short-cycle examination preparation institutions, called "frontistiria," and examination-targeting tutors, while the focus on preparing for the national examination has brought about a lessening in the quality of secondary education in Greece. Rationing has also led to record numbers of Greek students going abroad for a university education (Psacharopoulos, 2003).

Free university education is not, of course, truly free. In the first place, there is the direct social cost, which is estimated to be about $€ 4.200$ annually ${ }^{1}$, which is funded by Greek taxpayers,

1 Calculation based on the latest (2008) OECD information about Greek government expenditures on higher education (OECD, 2016) and announcements from the Hellenic Ministry of Education, Research and Religious Affairs (2015) and in Hellenic Ministry of Finance regular budgets (2008 to 2015) that between 2008 and 2015 government expenditures in all sectors decreased by at least $30 \%$ due to the economic crisis. 
PROBLEMS

OF EDUCATION

IN THE $21^{\text {st }}$ CENTURY Vol. 76, No. 4, 2018

438

ing parents of students. The foregone earnings of the student while at a university, estimated to be about $€ 6.000$ per year, is another social and private cost. Two additional private costs that families and students bear are the cost for preparing for the highly competitive national examinations determining university entrance and costs incurred for rent, food, books, travel, and other necessities while studying at a university. In regard to these two additional private costs, a year 2000 study of 3.000 first-year students in eight Greek universities found that despite the claim that university education is free in Greece, Greek families actually spent more privately than the state did to help their children prepare for entrance examinations and for their university studies (Psacharopoulos \& Papakonstantinou, 2005). The analysis also showed inequities related to family income, with poorer families spending a higher proportion of their income, compared to wealthier families, to prepare their children for university and during university attendance. For instance, families in the bottom $20 \%$ of annual income spent $26.4 \%$ of that income for a child attending university, while families in the top $20 \%$ of income spent $9.6 \%$ of their income for the same purpose. In addition, students whose fathers were manual laborers or farmers were relatively poorly represented in university compared to students whose fathers were executives, managers, or other white-collar workers. The analysis concluded that private expenditures on higher education seemed to be a necessity for Greek families, with income elasticity calculated as falling between 0.2 and 0.3 . Based on these results, the researchers recommended that the Greek government reallocate its funds for higher education to provide more financial help for families of students at lower socioeconomic levels and that major improvements be made to Greek public secondary education so that student families would have less need to spend on private preparation for university entrance.

Since the study by Psacharopoulos and Papakonstantinou (2005), much has happened in the economy of Greece. In 2010, Greece entered an economic crisis that by 2015 had led to a seriously contracting economy, high unemployment, and more than a one-third reduction in government educational expenditures (Dassiou, 2015). In the wake of this major economic downturn, it seemed unlikely that the inequities revealed by the 2000 study would be substantially remedied. However, with no extant empirical evidence regarding possible changes, it was deemed possible that some progress had been made in reducing Greek families' private expenditures for tertiary education, the inequities found in the 2000 study, or both. The problem for the study reported here was to determine whether any advance has been made since the year 2000 in relieving the private costs for Greek students' preparation for and attendance at Greek universities or reduction of the inequities revealed in the 2000 study.

By examining the extent of families' private investments in tertiary education for their children, the study has relevance for other countries that have government mandated free higher education. The study is especially relevant for countries which, like Greece, require students to take a national examination to determine eligibility to enter a public university. Among these countries are Turkey (Kondekci \& Orucu, 2017); Brazil, the People's Republic of China, Russia (Schwarzman \& Knobel, 2016); and Japan (Koyama, Matsushita, Ushijima, Jono, \& Ikeda, 2014). The study also has special relevance for Europe at a time when substantial cuts are being made to higher education in a number of European countries, including replacing need-based grants with loans in the UK and the Netherlands, potentially adversely affecting the ability of poorer students to attend a higher education institution (Vikmane \& Atonescu, 2016). Making it more difficult for poorer students to enrol in and complete tertiary education undercuts the goal of achieving greater economic equality in European countries (Rodriguez-Pose and Tselios, 2009) and has a number of adverse consequences for those students. These consequences include a greater likelihood that employees without a tertiary degree will be at risk in coming years of their jobs being replaced by automation (Bubbico \& Freytag, 2018). Furthermore, adverse health consequences have been found to be associated with lack of a higher education. In particular, the Organisation for Economic Cooperation and Development (OECD) and the European Commission (EC) found that in all OECD-EC states, the life expectancy at age 65 of both men and women with a tertiary education was greater than that of men and women with 
less than an upper secondary education, with the difference being as much as 4.4 years for men and 2.7 years for women (OECD, 2017).

\author{
PROBLEMS \\ OF EDUCATION \\ IN THE $21^{\text {st }}$ CENTURY \\ Vol. 76, No. 4, 2018 \\ 439
}

\section{Methodology of Research}

\section{Data Collection}

Data for this research were obtained from a European Union two-phase research program called "Thales." ${ }^{2}$ The survey was first administered in 2000 and then again in late 2014 and early 2015. The 2014-2015 questionnaire was submitted to a 15\% random sample of first-year Greek University (AEI) students in 58 departments across seven central and regional Greek universities. Universities were chosen based on the criteria of the size of their student populations and whether the university administration decided to allow the survey to be conducted. A total of 2.370 students responded to the 2014-2015 survey (see Appendix Table A-1).

\section{Instrument}

The questionnaire used in both the year 2000 and 2014-2015 studies was developed by researchers for the EU program and was approved by the research program committee. In addition to demographic items, the survey included questions asking for socio-economic characteristics of students' families, private expenditures for preparing for the national examination and university entrance, and expenditures during university study. The researchers visited each of the seven universities to administer the survey to students in paper-and-pencil form.

\section{Data Analysis}

Using the SPSS statistical program, results of the 2014-2015 survey were compared to results from the year 2000 survey, which was administered to over 3.000 students comprising a 10\% random sample of first-year students in eight Greek universities, six of which were also included in the more recent survey. The purpose of the comparison was to learn what changes may have occurred in regard to Greek families' private expenses for tertiary education since the year 2000, which was especially of interest given the recent economic downturn in Greece.

\section{Results of Research}

Results of the analysis of data from the 2014-2015 survey of first-year university students are detailed. These are compared to the results from the year 2000 administration of the survey to determine any changes occurring during the approximately 15 -year period between the two survey administrations. Of special interest are what the more recent survey shows about Greek families' private expenditures for their children's preparing for and attending a Greek university and what the recent survey results suggest about inequalities of university attendance between students with different socioeconomic backgrounds.

\section{Demographic Results}

Demographic results of the 2014-2015 survey (see Appendix Table A-2) showed that the trend of increasing female enrollment compared to male enrollment continues in Greek

2 Research program: "Thales", Action 4: "Economic Burden of Admission to Higher Education" co-financed by the European Union (European Social Fund - ESF) and Greek national funds through the Operational Program "Education and Lifelong Learning" of the National Strategic Reference Framework (NSRF). Greek Ministry of Education, Lifelong Learning and Religious Affairs 
PROBLEMS

OF EDUCATION

IN THE $21^{\text {st }}$ CENTURY Vol. 76, No. 4,2018

440 were female, the more recent survey showed that the proportion of females had increased to $64.3 \%$ of the students, while $35.7 \%$ were males.

Average parental schooling has risen in the intervening years. Parental schooling indicated in the older survey approximated the completion of secondary education, while parental schooling for the recent survey showed that $42 \%$ of fathers and $47 \%$ of mothers had received a University (AEI) or Technical Institute (TEI) education. An additional 15.6\% of fathers and $7.5 \%$ of mothers had attended a technical school after lyceum.

In the older survey, about six percent of the students had attended a private lyceum. In the newer sample, nine and one-half percent had done so. Whereas the grade for the last year of lyceum that was taken into account for the year 2000 results was nearly 18 out of 20, it was slightly over 18 for the newer survey.

\section{Competitiveness and Inequity of University Entrance}

The students in the 2014-2015 sample took the Greek higher education entry examination in the summer of 2013. In that year, there were nearly 104.988 candidates applying for a university place. Of these, 46.633 candidates entered a university (AEI) and 22.959 entered technological institutes (TEI) that are in a lower demand. (Hellenic Ministry of Education, Research and Religious Affairs, 2013). From the 2.370 students who entered university in our sample, only 1.416 entered the department or university of their first choice.

Table 1 shows how father's income generally increases with education for the 2014-2015 sample. Compared to figures from the earlier survey, incomes are higher for all educational levels, with eight to nine percent increases applying to Gymnasium and Lyceum education. However, university income during the approximately 15-year period increased by only slightly over three percent. Comparing income averages by years of schooling, and using the shortcut method (Psacharopoulos \& Ng, 1994), it is evident that returns to university education compared to lyceum education are $5.9 \%$. This is a reduction of $1.5 \%$ from the results of the old survey, with the reduction likely being the result of the economic downturn that led to increased unemployment among young university-educated individuals during the time the survey was administered (OECD, 2014). The reduction in the returns of a university education may also reflect lower mean wages for university graduates due to a full job market and a flattening out of wages for graduates in areas such as the Humanities and Education (Livanos \& Pouliakas, 2011). The returns for higher technical education compared to lyceum only education continue to be negative, as they were for the year 2000 survey.

Table 1. Mean father's income by father's education.

\begin{tabular}{cccc}
\hline Educational level & Income (€/year) & Years schooling & Percent sample \\
\hline Primary & 12432 & 6 & 8.0 \\
\hline Gymnasium & 13748 & 9 & 8.3 \\
\hline Lyceum & 16384 & 12 & 22.1 \\
\hline Higher technical & 15273 & 14 & 15.6 \\
\hline University & 20282 & 16 & 42.0 \\
\hline
\end{tabular}

The figures in Table 1 support the main reason university attendance is free in Greece, which is to provide equal opportunities for both rich and poor students to enter a university. We see in the last column of Table 1 that almost 60 percent of the students' fathers had less than a university education in 2014-2015. But nearly $70 \%$ of the students surveyed will have graduated from the university by 2019 (Hellenic Ministry of Education, Research and Religious Affairs, 2015). This, when added to the finding that compared to results from the older survey, 
a higher proportion of students' parents in the more recent survey are university graduates, provides further evidence of the substantial social mobility that comes from the Greek higher education system.

Yet, when we use parental occupation to index university students, results continue to indicate inequities of university representation that were present in the earlier survey (see Table 2). In particular, students whose father is a farmer or manual worker are substantially underrepresented compared to the occupation's labour force share. Students whose fathers are farmers or work in fisheries, for example, constitute only a little over five percent of the sample, just a few tenths of a percentage more than they did almost 15 years ago. At the same time, students whose father is an executive, manager, or white-collar worker are well represented among the survey takers, making up over three-quarters of the students.

These results suggest a limitation on the upward mobility provided by a university education for some low-income labour force segments ${ }^{3}$.

Table 2. The inequity of university access (\%).

\begin{tabular}{cccc}
\hline Father's occupation (1) & Labour forc share ${ }^{\mathrm{a}}(2)$ & Student entrants share (3) & Representation index $^{\mathrm{b}}$ (4) \\
\hline $\begin{array}{c}\text { Executive and } \\
\text { occupation }\end{array}$ & 21.7 & 17.0 & 78 \\
\hline White collar worker & 33.9 & 62.3 & 184 \\
\hline Farmer/Fisherman & 11.6 & 5.2 & 45 \\
\hline Manual worker & 24.0 & 5.0 & 21 \\
\hline Casual employment & 8.8 & 3.5 & 40 \\
\hline a'Hellenic Statistical Authority, 2015 & & &
\end{tabular}

Entry Preparation

The finding that a substantially lower percentage of university students have fathers employed in lower-income than in higher-income labour segments raises the question of whether this may be due to a difference in preparation for the two groups of students. In Greece, the national examinations that have a large part in deciding whether a student is accepted into a university are very competitive. As a result, secondary students usually begin preparing for the examinations several years ahead. This typically involves attending examination preparatory schools called "frontistiria", engaging a private tutor, or both (Kostakis, 1990).

In the recent sample, $82.7 \%$ of students had attended frontistiria, and $47.9 \%$ had a private tutor. Over one-third of the students had engaged in both methods of preparation. These proportions were similar to those for the previous sample (84\% frontistiria and $50 \%$ private tutor). Students in the newer sample spent an average of 2.2 years in frontistiria and 2.0 in private lessons, compared to 2.4 and 1.8 years, respectively, for the older sample. A majority $(89.5 \%)$ of the newer sample succeeded on the national examination the first time, with 1.1 years being the average for examination success. This is in comparison to an average of 1.7 years for the older sample. Eighty-one percent of the newer students graduated from secondary school in 2013,10\% in 2012, and nine percent earlier.

3 Notably, the percentage of students in the recent survey who had a father employed in the executive and managerial category, though substantial, was considerably less than the 26.0 percent that was recorded for the earlier study. One reason for this decline may be the fact that after the economic downturn beginning around 2008, more high-income families began sending their children to institutes of higher education in countries outside of Greece (Papakonstantinou 2015). At the same time, the percentage of students with fathers in white-collar jobs increased from 48.0 to 62.3 . This increase may partly reflect the larger labor force share for white-collar workers in recent years (33.9\%) compared to the $31.4 \%$ at the time of the earlier study. 
Marilou IOAKIMIDIS, George PAPAKONSTANTINOU. The true private cost of a "free" university education: A comparative study

PROBLEMS

OF EDUCATION

IN THE $21^{\text {st }}$ CENTURY Vol. 76, No. 4, 2018

The question of what differences in preparation there may have been for various characteristics of the recent sample are partly addressed in Table 3 . The figures there indicate a considerable similarity between different groups, especially in their probability of frontistiria attendance. However, the figures also suggest that there is a substantial difference between higher and lower income groups in regard to families hiring a private tutor.

Table 3. Probability of attending preparatory schools and having individual tutoring by selected sample characteristics.

\begin{tabular}{ccc}
\hline Characteristic tutoring & Preparatory School (Frontistiria) & Individual tutoring \\
\hline Male & .86 & .45 \\
\hline Family residence $<10000$ pop & .81 & .53 \\
\hline Father manual worker & .82 & .36 \\
\hline Father farmer/fisherman & .85 & .35 \\
\hline Father executive & .82 & .55 \\
\hline Private lyceum & .63 & .64 \\
\hline Bottom 20\% family income & .81 & .36 \\
\hline Top 20\% family income & .77 & .59 \\
\hline Overall & .83 & .48 \\
\hline
\end{tabular}

Table 4 shows what families spend privately per student while the student is in secondary school. These amounts continue to be comparable to what the state spends per student at that level of education (OECD, 2012). Evidently, even with the economic downturn, the cost for university preparation has grown substantially over the intervening years after the older survey, with total expenditures for various groups ranging from about a $75 \%$ increase to well over twice what was reported in the older survey.

Table 4. Private preparatory expenditure per student by selected sample characteristics ( $€ /$ year) ${ }^{\mathrm{a}}$.

\begin{tabular}{ccccc}
\hline Characteristic & $\begin{array}{c}\text { Prep. school } \\
\text { (Frontistiria) }\end{array}$ & Individual tutoring & Private lyceum & $\begin{array}{c}\text { Total entry } \\
\text { expenditure }\end{array}$ \\
\hline $\begin{array}{c}\text { Family residence }<10 \\
\text { 000 pop }\end{array}$ & 3454 & 4070 & 5825 & 5223 \\
\hline $\begin{array}{c}\text { Father farmer/fisher- } \\
\text { man }\end{array}$ & 3819 & 4653 & 0 & 5010 \\
\hline $\begin{array}{c}\text { Father manual } \\
\text { worker }\end{array}$ & 3269 & 3520 & 3000 & 4397 \\
\hline Father executive & 3824 & 6250 & 6324 & 6178 \\
\hline $\begin{array}{c}\text { Bottom 20\% family } \\
\text { income }\end{array}$ & 3488 & 3644 & 4842 & 4630 \\
\hline $\begin{array}{c}\text { Top 20\% family } \\
\text { income }\end{array}$ & 4027 & 5787 & 6300 & 7830
\end{tabular}

${ }^{a}$ Columns 2, 3, and 4 reports mean amounts for all families whose students engaged in the indicated type of preparation. Column 5 reports mean amounts spent by families for all types of preparation their students engaged in. 
These findings provide evidence for an extension of the trend identified by Kassotakis and Verdis (2013), who found that private schooling in the form of frontistiria grew to employ 23,720 teachers in 2010-2011, an increase of more than 56\% from the early 1980 s. The researchers also noted that in Greece, it is "common knowledge" (p. 101) that the number or private tutors may exceed the number of frontistiria teachers, and they estimated that the total number of teachers involved in so-called shadow education in Greece may rival the number of teachers working in mainstream secondary schools. This is not surprising given that almost all final-year lyceum students receive some form of supplementary education (Liodakis, 2010). It appears from the current study that despite the serious economic downturn that Greece has been dealing with during the past several years, growth in the private education industry continues today.

\section{University Attendance Expenditure}

When a student enters a supposedly free higher education system and takes up his or her university studies, the family's private expenditure remains high (Table 5). While costs for each grouping represented in the table have increased over those reported in the earlier survey, percentage increases are not as great as they are for cost of preparation. Similar to the results from the older survey (shown in brackets in the fourth column), private expenditure is less than $10 \%$ of family income for students from families in the top quintile. Yet in the more recent survey, annual private expenditures for students from the bottom quintile have increased to where they amount to over $40 \%$ of family annual income. Much of this large increase is evidently due to the fact that income for the bottom quintile, as reported by students, is some $€ 3500$ less than it was almost 15 years ago, another apparent consequence of the economic downturn.

Table 5. Private expenditure per university student by selected sample characteristics.

\begin{tabular}{llll}
\hline Characteristic (1) & Expenditure (€/year) (2) & Family income (€/year) (3) $\begin{array}{l}\text { Exp./income (\%) new } \\
\text { [old] (4) }\end{array}$ \\
\hline $\begin{array}{l}\text { Family residence }<10000 \\
\text { pop }\end{array}$ & 4900 & 21372 & $22.9[21.8]$ \\
\hline Father farmer/fisherman & 5000 & 20199 & $24.8[28.6]$ \\
\hline Father manual worker & 4083 & 16471 & $24.8[21.8]$ \\
\hline Father executive & 5155 & 38630 & $13.3[13.4]$ \\
\hline Bottom 20\% family income & 3995 & 9576 & $41.7[26.4]$ \\
\hline Top 20\% family income & 5355 & 54876 & $9.8[9.6]$ \\
\hline University of loannina & 525 & & \\
\hline University of Athens & 3792 & & \\
\hline University of Patras & 5039 & & \\
\hline University of Thessaloniki & 4552 & & \\
\hline NTUA & 4104 & & \\
\hline University of Crete & 5033 & & \\
\hline University of Aegean & 5890 & & \\
\hline Overall & 4696 & & \\
\hline
\end{tabular}

Note: Col. (4) $=$ [Col. (2)/Col. (3) $]$ x 100. 
PROBLEMS

OF EDUCATION

IN THE $21^{\text {st }}$ CENTURY Vol. 76, No. 4, 2018

An amount of private expenditure while students are enrolled at a university is about equal to or more than what the estimated $€ 4200$ annually that the state spends per university student, as was the case for the older survey, while it was mostly less in the case of the older survey. A major component of the private student expenditure while at the university is rent for students living away from family. Private cost per student is similar for different universities, with the exception that students at University of Athens, NTUA, and the University of Thessaloniki pay less. This is partly because of the number who reside at home while at university. Surveyed students who pay zero monthly rent are highest for those three universities, at $44.9 \%, 50.4 \%$, and $31.5 \%$, respectively.

\section{Inelasticity of Greek University Education}

As it was done for the results of the older survey, a "consumption function" formula was applied to compare new results for household income to those for private expenditures for university preparation and attendance:

Ln (household education expenditure $)=a+b \ln$ (household income)

Regression results are shown in Table 6. The function has been fitted for two types of expenditures by families-for entry preparation while the student is in secondary school, and for expenses while at a university. Because both income and expenditures are entered into the regression in log form, the estimated b coefficient on income can be interpreted as the income elasticity of demand. These values are approximately 0.28 for entry preparation and 0.23 for expenditures while studying, compared to 0.30 and 0.18 , respectively, for the results of the older survey. The continuing income elasticities of between 0.2 and 0.3 indicate that university preparation and attendance continue to not be luxury items for families but rather necessities.

Table 6. Education expenditure functions.

\begin{tabular}{lcc}
\hline Independent variable & \multicolumn{2}{c}{ Log-expenditure } \\
\cline { 2 - 3 } & Preparing for entry & While in university \\
\hline Constant & 5.645 & 5.822 \\
\hline Log-family income & $0.282(12.7)$ & $0.234(6.6)$ \\
\hline $\mathrm{R}^{2}$ & 0.88 & 0.28 \\
\hline $\mathrm{N}$ & 1775 & 1775 \\
\hline
\end{tabular}

Note: Numbers in parentheses are t-ratios.

\section{Discussion}

Results of the more recent survey of students are similar to those of the older survey in a number of ways. At the same time, there are some notable differences. In regard to similarities, the correlations of father's income to father's educational completion level remains the same as it was for the older survey. Income resulting from a lyceum education continues to be more than for a higher technical education but less than for a university education. However, the difference in remuneration between a lyceum education and a university education has decreased substantially. While in the older survey, student reports of father's income for the various educational levels indicated that pay for a university education was $29.7 \%$ higher than for the lyceum level, the newer survey results showed that this percentage difference in income between the two educational levels had decreased to $23.7 \%$. A likely cause of the decrease is the 
fact that an excess of university-educated potential employees have flooded the labour market, driving down wages and leaving a substantial percentage of university-educated applicants unemployed.

There are also notable differences between the two surveys in the educational levels of fathers as reported by students. In the older survey, $24.8 \%$ of students' fathers had only a primary or gymnasium education. The newer survey shows this figure reduced to $16.3 \%$, a decrease of about one-third. At the same time, percentage of fathers with a university education has increased from $38.2 \%$ to $42.0 \%$. These figures reflect the increasing pressure in Greece to obtain a university education. This pressure is also reflected in the probability that surveyed students attended a "frontistirio" or had individual tutoring in preparation for the national university entrance examination, a probability that remains high overall.

The use of "shadow education" services in the form of frontistiria and private tutoring leads to substantial private education expenses for families at all socio-economic levels in Greece, though the burden falls most heavily on the lower levels. Based on data from 2007, Liodakis (2010) estimated that Greek households spent 1.7 billion euros annually on supplementary education in the form of frontistiria and private tutoring. Despite the considerable expenses involved, the majority of Greek families seem to have accepted supplementary education expenses as a necessity and have done so even while having to face stringent austerity measures over the past several years. Indeed, the concept of shadow education appears to have become completely normalized in Greek society (Kassotakis \& Verdis, 2013). Prior research has found social inequalities in the use of the two basic forms of supplementary education, with families of lower socio-economic position being less likely to employ private tutors than families of higher standing (Polychronaki, 2004). This was also found to be the case in the present research, with the highest quintile families $60 \%$ more likely than the lowest to employ private tutors.

Why so much pressure in Greece to attend a university? This pressure is motivated by the principle that higher wages are the basic direct return of education at all levels, a principle that is certainly true of a university education. Accordingly, the most important reason for students to desire a university education is to increase their opportunity to gain a position paying higher wages than would otherwise be the case. Other, more indirect, returns to a university education include an increased probability of a university-educated employee ascending to a higher position in a company (which of course also typically results in the direct return of earning more money) as well as social class mobility since a person with a university degree can more easily move upward in social class, again often with an attendant increase in standard of living.

The widely held conviction in Greece that substantial direct and indirect returns follow from a university-level education motivates students and their families to aspire to a university education. The belief that education is a key to higher income is held by parents of all social and economic classes, including those whose own educational attainment is not great. As a result, parents with limited or no education often pressure their children to follow the path of higher education. Perhaps the main reason is that they do not want to see their children economically deprived as they, the parents, had been by being employed at a low-paying job such as in manual work and farming, which are generally considered to be inferior jobs in Greece. Universityeducated parents also can be expected to pressure their children to continue the family tradition by entering a university. This pressure is increased by the circumstance that in Greece, the family is held in great value, as demonstrated by the common occurrence of family nepotism in organizations. The importance of families is also reflected by the fact that many students follow their father's career path even though their first choice of career may be quite different. If that career path requires a university education, then such an education becomes a virtual necessity in the minds of parents and their children. (Mitsopoulos \& Pelagidis, 2011, Bozionelos, 2014)

One surprising result of the new survey was the substantial increase in the cost of university preparation since the previous survey. This increase occurred for each mode of preparation-frontistiria, private tutor, and private lyceum - and overall. Percentage increase in 
PROBLEMS

OF EDUCATION

IN THE $21^{\text {st }}$ CENTURY Vol. 76, No. 4, 2018

446

yearly expense for university education was smaller than the increase for university preparation. The result was that private cost of university preparation outran the private cost of university expenses for the new survey results, which was opposite the finding for the older survey, where annual university expenses were greater than cost for university preparation. This change may be another reflection of the circumstance that university education is considered a necessity, not an option for most Greek families as reflected in the income elasticities that were derived from our consumption function. Because high scores on the national university entrance exams are a key to university entrance for most students, becoming well prepared for those tests has become a necessity in itself. It should be noted that calling frontistiria and private tutoring by the name "university preparation" is somewhat of a misnomer. These instructional modalities are not so much preparation for university itself, but rather preparation for scoring high on an exam that will enable a student to enter a university.

Adopting the position that everyone must have a higher education degree and that all manual or farming jobs are inferior has resulted in serious imbalances in the Greek labour market. Today, job opportunities for university graduates are currently very limited due to the relatively small size of a Greek labour market that has shrunk further as an aftermath of the economic crisis. Yet there is an enormous number of higher education graduates who refuse to work on a farm or in other manual labour, while there is only a relatively small number of Greek people who have not gained a university education and who work in the manual and farm sectors. The result is that Greece does not have enough manpower to perform work that must be done in those sectors, so economic migrants must be hired to fill this gap. (Theodosiou \& Pouliakas, 2005)

\section{Conclusions}

The main conclusion that can be drawn from the results of the 2014-2015 survey of university students is the same as was drawn for the results of the year 2000 survey. Despite the claim that higher education is free in Greece, that claim ignores a very important reality. The expenditures by families to prepare their children for being able to enrol in a university and incurred for actual attendance at a university exceed what the state spends per student. Furthermore, university education is deemed so necessary in Greece that those students who do not score high enough on the national entrance examinations to secure a place in a university often enrol in universities abroad, where they may spend even more than they would have done at a Greek university.

The results also make clear that the families of students from a lower socioeconomic level spend a substantially higher proportion of their income on university preparation and attendance than families from higher socioeconomic backgrounds. This circumstance limits social mobility by making it more difficult for poorer families to afford the expenses required to purchase examination preparation services and finance their students' university attendance. Thus, many students from poorer families may be restricted from a university education because of its lack of affordability. This limitation is reflected in the finding that the percentage of university students taking the new survey whose fathers worked on farms or fisheries stayed essentially constant from the old survey (5.2\% vs. 5.0\%). Even more telling, the percentage of students who took the new survey whose fathers were manual workers decreased to $5.0 \%$ from $14.0 \%$ in the old survey.

These findings strongly suggest the value of reallocating the Greek university financial budget to redress this imbalance. More money could be spent on supporting the university aspirations of lower-income students by relieving some of the financial burden their families bear in preparing them for the university entrance examinations and supporting them at a university. This assistance could take the form of stipends available to lower-income families that can document their yearly income and their student-related expenses.

This study also again raises the question of the wisdom of making preparation for the 
national university entrance examinations a key focus of secondary education. Due to the competitiveness of university entrance, not only do frontistiria and private tutors target those examinations, but both public and private lyceums are often focused on preparing secondary students for answering national examination questions correctly. A result of this focus is less time spent in the lyceums and in students' lives on the kind of quality, well-rounded education that would better enable Greece to compete successfully in a world increasingly dependent on information and workers who are broadly knowledgeable, resourceful, and innovative. Ironically, the intense focus on an examination whose purpose is to determine university entrance may actually be diluting the kind of education that would better prepare university students to excel in their studies. If ways could be found to take the financial resources currently needed for examination preparation and re-target them into the lyceum, the quality of secondary education in Greece might rise significantly, with resulting benefits not only for students but for the future of the nation.

In sum, comparing the results from the 2014-2015 survey to those of the year 2000 survey indicates that there has been little change in the past 15 years in regard to private expenditures for university education. The more recent survey results indicate that the pay differential for university graduates compared to lyceum graduates has decreased, possibly due to an excess of university-educated potential employees driving down wages and leaving many universityeducated applicants unemployed. Educational level of students' fathers has increased, with $42.0 \%$ having a university education, which likely reflects the pressure in Greece to obtain a university education. Income elasticity remains between 0.2 and 0.3 , indicating that families consider university preparation a necessity, not a luxury. Inequities continue for university representation, with students whose fathers are in lower-income occupations under-represented in universities compared to students with fathers in higher-income occupations, suggesting that the upward mobility provided by a university education is limited for low-income labour force segments ${ }^{3}$.

Further research is needed to close gaps in knowledge about the private costs of university education in Greece. In particular, research is needed to determine to what degree families' investment in preparing their child for the national examinations leads to a successful outcome. Researchers could examine this question in respect to possible differences in success rates for various income groupings. The failure of a lower-income student to achieve a passing score on the national examinations may be especially detrimental for their families due to the larger percentage of the family income spent on student preparation costs. Yet, lower-income families may not be able to afford as high-quality a preparation as higher-income families, which may make a difference in the success rate of their students on the national examinations. It would thus be informative to determine student success rates for passing the national university entrance examinations for the various income groups.

\section{Acknowledgement}

The authors thank G. Psacharopoulos for his contribution, comments, and suggestions.

\section{References}

Bozionelos, N. (2014). Careers patterns in Greek academia: Social capital and intelligent careers, but for whom? Career Development International, 19 (3), 264-294.

Bubbico, R. L., \& Freytag, L. (2018). Inequality in Europe. Retrieved from the European Investment Bank website, http://www.eib.org/attachments/efs/econ_inequality_in_europe_en.pdf.

Fokkema, T., ter Bekke, S., \& Dykstra, P. A. (2008). Solidarity between parents and their adult children in Europe. Netherlands Interdisciplinary Demographic Institute reports, 76. Amsterdam, Netherlands: KNAW Press.

Hellenic Ministry of Education, Research and Religious Affairs [Ypourgeio Paideias Ereunas kai Thriskeumaton]. (2015). Online education statistics and projections. Retrieved from http://www. minedu.gov.gr/.

PROBLEMS

OF EDUCATION

IN THE $21^{\text {st }}$ CENTURY

Vol. 76, No. 4, 2018

447 
Marilou IOAKIMIDIS, George PAPAKONSTANTINOU. The true private cost of a "free" university education: A comparative study

PROBLEMS

OF EDUCATION

IN THE $21^{\text {st }}$ CENTURY Vol. 76, No. 4, 2018

448

Hellenic Ministry of Finance (Ypourgeio Oikonomikon). (2008-2015). Regular budgets. Online Greek budget data, retrieved from http://www.minfin.gr/ (in Greek).

Hellenic Statistical Authority (Elliniki Statistiki Arhi). (2015). Labour force survey. Online Greek survey results, retrieved from http://www.statistics.gr/ (in Greek).

Kassotakis, M., \& Verdis, A. (2013). Shadow education in Greece. In M. Bray, A. E. Masawi, \& R. B. Sultana (Eds), Private tutoring across the Mediterranean (pp. 93-113). Rotterdam, Netherlands: Sense Publishers.

Kondakci, Y., \& Orucu, D. (2016). Tertiary schooling patterns and disadvantaged groups in Turkey. In M. Shah \& G. Whiteford (Eds.). Bridges, pathways and transitions: International innovations in widening participation (pp. 209-226). Amsterdam, Netherlands: Chandos Publishing.

Kostakis A., (1990) Vocational and academic secondary education in Greece: Public and private costs compared. Economics of Education Review, 9 (4), 395-399.

Koyama, A., Matsushita, M., Ushijima, H., Jono, T., \& Ikeda, M. (2014). Association between depression, examination-related stressors, and sense of coherence: The ronin-sei study. Psychiatry and Clinical Neurosciences, 68 (6), 441-447. doi: 10.1111/pcn.12146.

Liodakis, N. (2010, June). The development of supplementary educational institutions and educational mobility in Greece. Paper presented at The World-wide Growth of Supplementary Education Workshp, University of Waterloo, ON, Canada.

Livanos, I., \& Pouliakas, K. (2011). Wage returns to university disciplines in Greece: Are Greek higher education degrees Trojan Horses? Education Economics, 19 (4), 411-445.

Mitsopoulos M., Pelagidis T. (2011). Understanding the crisis in Greece: From boom to bust. Houndmills, UK: Palgrave Macmillan.

OECD. (2014). Employment outlook 2014: How does Greece compare? Paris: OECD. Online report. Retrieved from https://www.oecd.org/greece/EMO-GRC-EN.pdf.

OECD. (2016). Education at a glance 2016. Paris: OECD. Online publication, retrieved from http:// download.ei-ie.org/Docs/WebDepot/EaG2016_EN.pdf.

OECD. (2017). Understanding the socio-economic divide in Europe: Background report. Paris: OECD. Online report. Retrieved from https:/www.oecd.org/els/soc/cope-divide-europe-2017background-report.pdf.

Papakonstantinou, G. (2003). Prosfora kai Zitisi Tritobathmias Ekapdeusis [Supply and demand for higher education]. Athens, Greece: Metaixmio Publishing.

Papakontantinou, G. (2015). Access to higher education. Study of social, educational and institutional dimensions of higher education demand, of its problems and completion policies -A comparative and empirical approach. Athens, Greece: University of Athens.

Polychronaki, M. (2004). Ekpaideutiki kinitikotita kai para-ekpaideutikoi mihanismoi. O rolos tou idiotikou kostous ekpaideusis [Educational mobility and para-educational mechanisms: The role of private cost of education]. Sciences of Education, 1, 47-64.

Psacharopoulos, G. (2003). The social cost of an outdated law: Article 16 of the Greek Constitution. European Journal of Law and Economics, 16 (3), 123-137.

Psacharopoulos, G., \& Ng, Y. C. (1994). Earnings and education in Latin America. Education Economics, $2(2), 187-207$.

Psacharopoulos, G., \& Papakonstantinou, G. (2005). The real university cost in a "free" higher education country. Economics of Education Review, 24, 103-108.

Rodríguez-Pose, A., \& Tselios, V. (2009). Education and income inequality in the regions of the European Union. Journal of Regional Science, 49 (3), 411-437.

Schwartzman, S., \& Knobel, M. (2016, spring). High-stakes entrance examinations: A view from Brazil. International Higher Education, 85. Retrieved from https://ejournals.bc.edu/ojs/index.php/ihe/ article/viewFile/9242/8297.

Theodosiou I., \& Pouliakas K. (2005). Socio-economic differences in the job satisfaction of high-paid and low-paid workers in Greece. Economic Bulletin, Bank of Greece, 24, 83-115.

Vikmane, L., \& Antonescu, A. (2016, May 27). Higher education funding - Towards greater inequality? University World News, 415. Retrieved from http://www.universityworldnews.com/article. php?story $=20160524143025838$. 


\section{Appendix}

PROBLEMS

OF EDUCATION

IN THE $21^{\text {st }}$ CENTURY

Vol. 76, No. 4, 2018

449

Table A-1. Sample distribution.

\begin{tabular}{llr} 
University & $\begin{array}{l}\text { Number of students } \\
\text { in the sample }\end{array}$ & $\begin{array}{c}\text { Percen } \\
\end{array}$ \\
\hline & & 18.1 \\
University of loannina & 428 & 25.6 \\
University of Athens & 606 & 16.4 \\
University of Patras & 389 & 18.9 \\
University of Thessaloniki & 447 & 5.4 \\
National Technical University of Athens & 139 & 13.4 \\
University of Crete & 318 & 1.8 \\
University of the Aegean & 43 & 100 \\
Total & 2370 &
\end{tabular}

Note: 15 percent random sample of all 2014 entrants, based on data from the Hellenic Ministry of Education, Research and Religious Affairs (2014). 
PROBLEMS

OF EDUCATION

IN THE $21^{\text {st }}$ CENTURY

Vol. 76, No. 4, 2018

Table A-2. Descriptive statistics (numbers in parentheses are the results from the 2000 survey).

Variable Mean or Proportion

$\mathrm{N}$

Background

Male

$0.36(0.38) \quad 2370$

Family residence under 10000 pop

Father's years of study

$0.21(0.21) \quad 2346$

Mother's years of study

13.72

2354

Father farmer

13.80

2362

Father manual worker

Father white collar worker

$0.05(0.05)$

2208

$0.05(0.14) \quad 2208$

Father executive

$0.56(0.48)$

2208

$0.17(0.26)$

2208

Family income (€/year)

25869 (22 020)

1777

Lyceum

Private lyceum

$0.09(0.06)$

2356

Private lyceum fees (€/year)

6038 (2823)

195

Lyceum graduate grade

$18.55(17.97)$

A. Preparatory school

Attended prep school

$0.83(0.83)$

2370

Years prep school

$2.21(2.40)$

1962

Prep school exp (€/year)

3659 (1966)

1740

$B$. Individual tutoring

Had private tutoring

$0.48(0.50)$

2370

Years priv. tutoring

$2.02(1.81)$

1150

Priv. prep exp (€/year)

4581 (2446)

972

Transition

Year graduated lyceum

$2012.6(1998.1)$

2370

Entry attempts

$1.12(1.71)$

2367

Preference order

$1.60(2.68)$

2363

University

Rent expenditure (€/year)

1705 including 0 reply

1972

2563 without 0 reply

1334

Total university study cost (€/year)

4448 (3754)

1835

Received: March 30, 2018

Accepted: July 12, 2018

\begin{tabular}{|ll|}
$\begin{array}{l}\text { Marilou loakimidis } \\
\text { (Corresponding author) }\end{array}$ & $\begin{array}{l}\text { Assistant Professor, University of Peloponnese, Greece \& } \\
\text { Visiting Professor, National and Kapodistrian University of Athens, De- } \\
\text { partment of Economics, Greece. } \\
\text { E-mail: marilou@uop.gr, mioakeim@econ.uoa.gr }\end{array}$ \\
\hline George Papakonstantinou & $\begin{array}{l}\text { Professor, National and Kapodistrian University of Athens } \\
\text { Department of Philosophy, Pedagogy and Psychology, Greece. } \\
\text { E-mail: gpapako@ppp.uoa.gr }\end{array}$ \\
\hline
\end{tabular}

